\title{
MOBY-DICK: THE READER AND THE ACT OF COGNITION
}

Bryce Conrad

EN ROUTE TO board the packet schooner for Nantucket, Queequeg recalls his first encounter with a wheelbarrow. Not comprehending the unfamiliar object's function, he tied his sea chest to it and then proceeded to hoist the entire affair onto his shoulders for transport. Ishmael's incredulous reaction to the story might well be that of any "civilized" man: "Queequeg, you might have known better than that, one would think. Didn't people laugh?"' The reply to Ishmael's query comes in the form of another tale-this time one about a sea captain who attended a wedding feast on Queequeg's native island of Kokovoko. Unfamiliar with the particular dining protocol of his hosts, the visitor decided to take his lead from the island king who dipped his fingertips into a large bowl of liquid which had been placed before the assembled company. The captain surmised that the king's actions meant washing was in order before the meal, and he proceeded to bathe his hands in what turned out to be a ceremonial wedding beverage freshly consecrated by the king's fingers. Queequeg pointedly returns Ishmael's question: "Now. . what do you tink now?-Didn't our people laugh?" (p. 59). Ishmael does not respond. The reader is left to ponder for himself whether Queequeg's people laughed or not at witnessing an act probably no less strange to them than a man carrying a loaded wheelbarrow on his back would be to Ishmael. Yet certainly something more instructive emerges from the juxtaposition of these two tales than a brief lesson in comparative anthropology. For if Queequeg "might have known better" than to lift a wheelbarrow onto his back, by what cognitive process could he arrive at such knowledge? Is there something in the wheelbarrow itself which makes Queequeg's use of the object "less correct" than civilized man's? Even if one assumes that the wheelbarrow's maker constructed the object to possess a particular function and that all other uses to which it might be put are merely interpretive "mistakes," can one in turn also posit a heuristic component in the object which will ensure that the maker's purpose is fulfilled? What is to prohibit the individual-as in the case of the sea captain-from interpret- 
ing the significance of an unfamiliar object or phenomenon within a range of possibilities determined by the norms of his familiar experience and knowledge? One may view the problem as purely anthropological if the thing or event in question belongs to the ordinary experiential world of one group of people or another. Yet Moby-Dick concerns not only wheelbarrows on the docks of New Bedford and ceremonial practices among primitive societies, but "the interlinked terrors and wonders of God" (p. 99) which one encounters on "the unhooped oceans of this planet" (p. 171).

The whaling vessel provides the primary instrumentality for shifting these speculative questions to an epistemological level: "For many years past the whale-ship has been the pioneer in ferreting out the remotest and least known parts of the earth. She has explored seas and archipelagoes which had no chart" (p. 99) and penetrated "into the remotest secret drawers and lockers of the world" (p. 382). Furthermore, the ship sets forth the paradigm of obtaining "value" by voyaging into the unknown-the encounter with leviathan contains a promise of distilling his "essence" in a tangible and material form. Yet the whaling ship, unlike the cognizing minds of some of her crew members, sails on the premise of reducing whatever is unfamiliar in the whale to a familiar monetary value: ". . . for however peculiar ... any chance whale may be, they soon put an end to his peculiarities by killing him, and boiling him down into a peculiarly valuable oil" (p. 176) - and that "peculiarly valuable oil" is defined as such only within the context of the Nantucket market and the lamps of the world.

Thus the whalemen themselves-unless, like Flask, they accept the "values" of the Nantucket market with such assurance that they look upon leviathan as "but a species of magnified mouse" (p. 106)-may not be so guided in their probing of the unknown, for "of all sailors, they are by all odds the most directly brought into contact with whatever is appallingly astonishing in the sea; face to face they not only eye its greatest marvels, but, hand to jaw, give battle to them" (p. 156). Certainly neither Ishmael nor Ahab restricts his attempts to discover the significance and import of the unknown to the context provided by the Nantucket whaling market. However, the paradoxical proposition of desiring to "know" what is "unknown" -as the "Wheelbarrow" chapter has pointed out-presents no clear guidelines. Ahab may accost the whale himself with "Speak, thou vast and venerable head" (p. 264), but "not one syllable" does it utter. Ishmael may concede the "pyramidical silence" (p. 264) of the whale and endeavor to examine him anatomically piece by piece, but he finally declares, "Dissect him how I may, then, I go but skin deep; I know him not, and never will" (p. 318). Yet the inscrutability of the visible and the sensory leads Ahab to proclaim that "All visible objects, man, are but pasteboard masks. But in each event - in the living act, the undoubted deed-there, some unknown but still reasoning thing puts forth the moldings of its features from behind the unreasoning mask. If man will strike, strike through the mask!' (p. 144). 
Ahab, however, cannot avoid admitting, "Sometimes I think there's naught beyond" (p. 144). And even Ishmael reveals a desire to verify what might lie "beyond" when he longs to "leap the topmost skies, to see whether the fabled heavens with all their countless tents really lie encamped beyond my mortal sight!' (p. 233).

For the reader of Moby-Dick, the novel's overwhelming interpretive difficulties reside in the fact that knowing the unknown becomes as much his problem as it does any particular character's. The mysterious objects and phenomena encountered in reading the text-whether Queequeg's tattoos, the nightly spouting of a unseen sea creature, or the white whale himselfare not defined by the characters for the reader, but remain resonant symbols by which the characters themselves are partially defined. "The Doubloon" chapter offers the most explicit example. Ishmael wryly introduces that section with his observation that "some certain significance lurks in all things, else all things are worth little, and the round world itself is but an empty cipher, except to sell by the cartload, as they do in hills about Boston, to fill up some morass in the Milky Way" (p. 358). Then, in succession, Ahab, Starbuck, Stubb, Flask, the Manxman, and Pip attempt to discover "some certain significance" in the doubloon-six varied readings of the coin, yet as Stubb comments, "but still one text" (p. 362). The significance of the doubloon itself, however, remains the openness of possibility by virtue of each interpreter supplying his own subjective and "self-reflecting" context in order to effect his act of cognition. Ahab places the coin in the context of his quest to find "Who's over me?" (p. 144): "The firm tower, that is Ahab; the volcano, that is Ahab; the courageous, the undaunted, and the victorious fowl, that, too, is Ahab; all are Ahab; and this round gold is but the image of the rounder globe, which like a magician's glass, to each and every man in turn mirrors back his own mysterious self" (p. 359). The world "mirrors back" Ahab's "own mysterious self" because only through that self can he perceive the world - thus objects become opaque masks which admit not of the "beyond" unless one can "strike through the mask." The doubloon serves, in part, to reveal Ahab to the reader, just as it reveals Flask and his Nantucket market context: "I see nothing here, but a round thing made of gold, and whoever raises a certain whale, this round thing belongs to him. So what's all this staring about? It is worth sixteen dollars, that's true; and at two cents the cigar, that's nine hundred and sixty cigars" (p. 361). Stubb's attempt "at raising a meaning out of these queer curvicues here with the Massachusetts calendar" (p. 361) provokes the most telling comment on the act of reading or cognizing the significance in things: "Book! you lie there; the fact is, you books must know your places. You'll do to give us the bare words and facts, but we come in to supply the thoughts" (pp. 360-61). He might as aptly have stated that we come in to supply the context.

"I look, you look, he looks; we look, ye look, they look," (p. 362) says Pip. The reader, too, might try his hand "at raising a meaning" from the dou- 
bloon or the "book" of Moby-Dick, yet no final "objective" or stable interpretation can emerge from the novel itself because its contextual framework or border is, paradoxically, unframed and borderless. The Pequod takes the reader away from "safety, comfort, hearthstone, supper, warm blankets, friends, all that's kind to our mortalities" (p. 97), and into a "howling infinite" of "unshored, harborless immensities" (p. 116). Within such an unlimited vastness, the symbolic possibilities of objects and events retain a plurality undiminished in its potential by any specific context necessarily imposed upon them by the characters or reader in the act of cognition-for without a context, cognition remains impossible. In his The Philosophy of Symbolic Forms, Ernst Cassirer points out that "Every 'simple' quality of consciousness has a definite content only in so far as it is apprehended in complete unity with certain qualities but separately from others. The function of this unity and this separation is not removable from the content of consciousness but constitutes one of its essential conditions." 2 Cassirer's thinking here bears obvious affinities with Ishmael's assertion that "there is no quality in this world that is not what it is merely by contrast. Nothing exists in itself' (p. 55). And it is precisely this dependence of content on context which reveals the full extent of the reader's difficult position in attempting to grasp the symbolic elements of the text. For the novel often thwarts the reader's facile interpretations by showing that the contexts provided by man are invariably extensions of his familiar and habitual knowledge.

Queequeg's juxtaposed tales demonstrate that a wheelbarrow divorced from its familiar context resonates with as much symbolic possibility as an isolated hieroglyph. And without the familiar context of hand-washing before a meal, the king of Kokovoko dipping his fingers into the ceremonial bowl would appear as suggestively luminous as the "mystic gestures" which Ishmael associates with the whale's tail: ". . I have heard hunters who have declared them akin to Free-Mason signs and symbols; that the whale, indeed, by these methods intelligently conversed with the world" (p. 317). Furthermore, the novel's non-verification of any governing context in the universe at large raises the somewhat staggering consideration-implicit, however, in Moby-Dick-that all objects, events, motions, and phenomena may be innately symbolic and that the entire cosmos itself exists, like the novel, as a text of unfathomable pluralities. In a sense, Moby-Dick has taken the logical simplicities of late eighteenth-and early nineteenth-century natural theology with its teleological arguments for the existence of God, and has turned those simplicities into cognitive and metaphysical complexities. The grand scope of such an idea naturally induces speculation about the existence of a supreme context-whether Plato's realm of unchangeable forms, Kant's absolute being, or an omnipotent deity-which would enable man to posit the likelihood of a single meaning for things rather than to inhabit a world of symbolic pluralities. And within the textual world of the novel, few critics 
and readers have not speculated on the possible existence of a key or code which would render one stable meaning from Moby-Dick.

Yet unless the reader approaches the text with an already delineated value he wishes to extract-as the whaling vessel ostensibly goes to sea for a particular "value"-he must depend upon the novel itself to set out some kind of interpretive restraints. Carey H. Kirk comments, "In many respects, the novel's audience cannot react to it at all without being attracted and guided by the opposition between Ahab and Ishmael. These alternatives provide one of the few fences around an unmanageably expansive book and do set some limits on potential chaos."3 One might, however, challenge the validity of such a "fence" on the grounds that it implicitly assumes an oppostion between Ahab's and Ishmael's view of the world which primarily finds interpretive articulation in a piecing together of the epistemological theories that would seem to inform the thoughts and behavior of the two. Robert Zoellner's study of the novel is founded upon such a piecing together of Ahab's and Ishmael's implied theories of cognition: “. . . the difference between Ahab, the dramatic expositor of Moby-Dick and Ishmael, the narrative expositor, is epistemological. They do not agree on the relationship between perceiver and perceived. This disagreement lies at the root of Moby-Dick. If Ahab is right, then Ishmael is wrong; if Ishmael is right, then Ahab is wrong." "Yet Zoellner's rigorous application of this "disagreement" proves to be more of a critical construct than an interpretive border provided by the novel when he subsequently elevates Ishmael's "scientifically correct analysis of perception" at the expense of Ahab's "grossness of realization" which "sees only ugliness and malice in life" (Zoellner, pp. 26, 108, 115).

A similar approach is to define the luminous symbolism of Moby-Dick by contrasting it with the emblematic stasis of allegory, and hence to draw the distinction, as does Walter E. Bezanson, that Ishmael accepts a vision of symbolic potential while Ahab's "destruction follows when he substitutes an allegorical fixation for the world of symbolic potentialities." ${ }^{\prime}$ But here Bezanson seems, quite contradictorily, to posit for himself some governing force in the universe which metes out destruction for that act of allegorization on Ahab's part. Furthermore, to allegorize the world, one must know the absolute context which defines the emblematic meaning of objects and events-in this respect, Ahab does not allegorize the world but rather directs all his energy toward discovering whether the world is allegorical, indeed whether there is a supreme context. The distinction presents no mere critical quibble if one insists on establishing Ahab and Ishmael as the borders for the reader's responses to Moby-Dick. The often voiced critical claim that Ahab imperiously decides that whatever lies "beyond" must be "Evil," fails to take into account Ahab's own admission that there may be "naught beyond," and that Ahab circularly defines "Evil" as whatever is "beyond" and unseen. As his "complete man after a desireable pattern" (p. 390) 
indicates, Ahab demands the capability to know rather than proclaims his capacity for knowledge:

Imprimis, fifty feet high in his socks; then, a chest modelled after the Thames Tunnel; then, legs with root to 'em, to stay in one place; then, arms three feet through the wrist; no heart at all, brass forehead, and about a quarter of an acre of fine brains; and let me see-shall I order eyes to see outwards? No, but put a sky-light on the top of his head to illuminate inwards. (p. 390)

Ideally, Ahab rejects his own eyes, which can only gaze upon the "pasteboard masks" of the sensory world - he wants a window toward the cosmos in order to be illuminated "inwards" concerning an absolute context and $a$ meaning of things. Ultimately, he suffers from his incapacity for knowledge. Suggestive but inscrutable symbols such as Queequeg's hieroglyphic tattoos present a "devilish tantalization of the gods" (p. 399). Since Ahab cannot know their meaning is precisely why he so vehemently deprecates against all omens, dim intimations, and vague intuitions of "truth": "If the gods think to speak outright to man, they will honorably speak outright; not shake their heads, and give an old wives' darkling hint" (p. 452). Ahab's defiance is, finally, defiance of inscrutability, of "the dead blind wall" which "butts all enquiring heads at last" (p. 427). Yet Ishmael also examines the whale and finds "a dead blind wall" (p. 284). He posits at one point a "clear Truth" inaccessible to man, "a thing for salamander giants only to encounter" (p. 286). Ishmael may even succumb to a certain type of "monomania"-or more properly, "monophobia"-which manifests itself not in a physical assault on "the unseen thing," but in his feeling that it will inevitably remain "unseen" and inaccessible for those who seek it:

Were this world an endless plain, and by sailing eastward we could for ever reach new distances, and discover sights more sweet and strange than any Cyclades or Islands of King Solomon, then there were promise in the voyage. But in the pursuit of those far mysteries we dream of, or in tormented chase of that demon phantom that, some time or other, swims before all human hearts; while chasing such over this round globe, they either lead us on in barren mazes or midway leave us whelmed. (p. 204)

The statement may well serve as a metaphor for the reader's own cognitive chase of a meaning in Moby-Dick. And what provides an interpretive border for that chase is not any philosophical program or epistemological theory which either Ishmael or Ahab embodies for the reader, but the actual process by which the reader attempts to assemble a meaning for the textfor the reading of Moby-Dick constitutes the sole cognitive act in which the reader is engaged. At the most basic ontological level, the novel is simply an assemblage of words written or compiled for the reader. Here one must consider Ishmael not only as character, but also as narrator-for in this latter role he becomes, as A. Robert Lee suggests, a type of "monkey-rope" companion for the reader who would otherwise find himself hopelessly adrift among "the constituents of a chaos" (p.117). ${ }^{6}$ With the opening sentence of the "Loomings" chapter-"Call me Ishmael"- the narrator estab- 
lishes his prerogative to give instructions while the reader's continued reading of the text implies compliance with or fulfillment of those instructions. This dynamic interaction between narrator and reader immediately defines the two as mutually dependent - they are united by a "Siamese ligature" not unlike that which binds Ishmael and Queequeg in "The Monkey-Rope" chapter: "I seemed distinctly to perceive that my own individuality was now merged in a joint stock company of two. . . . Nor could I possibly forget that, do what I would, I had only the management of one end of it" (p. 271). Ishmael certainly does not forget-indeed, it would be difficult to find a narrator who evinces more care in manipulating his end of the line. Paradoxically, however, Ishmael's overt instructions to the reader seem to promise the immanence of a meaning rather than its absence. As Warwick Wadlington notes, Ishmael's language gives rise to "the cognitive impulse, the desire to obtain final answers from an alluring world that stimulates interpretation." Ishmael repeatedly commands the reader to look upon what appears to be puzzling and inexplicable, questions him as to its significance, and then delivers an explanatory statement:

Circumambulate the city of a dreamy Sabbath afternoon. Go from Corlears Hook to Coenties Slip, and from thence, by Whitehall, northward. What do you see?-Posted like silent sentinels all around the town, stand thousands upon thousands of mortal men fixed in ocean reveries. ... How then is this? Are the green fields gone? What do they here? But look! here come more crowds, pacing straight for the water, and seemingly bound for a dive. Strange! Nothing will content them but the extremest limit of the land... . Tell me, does the magnetic virtue in the needles of the compasses of all those ships attract them thither? (pp. 12.13)

Ishmael does not abandon the reader after this barrage of grammatical imperatives and queries have been directed at him, but offers an interpretation in the guise of an answer: "Yes, as every one knows, meditation and water are wedded for ever" (p. 13). After another round of questions for the reader, Ishmael concludes with the story of Narcissus, explicitly proffering it as "the image of the ungraspable phantom of life" and "the key to it all" (p. 14). If the reader senses some duplicity on the narrator's part in linking "the key to it all" with an "ungraspable phantom," Ishmael allays rather than exacerbates those incipient suspicions by involving him in an investigation of Ishmael's own motives for signing aboard a whaling ship rather than undertaking the accustomed voyage with the merchant service. He claims to "see a little into the springs and motives" and reveals that "one grand hooded phantom, like a snow hill in the air" had its place among "the wild conceits" which urged him on (p. 16). Yet in the implicit link between Ishmael's "one grand hooded phantom" and "the ungraspable phantom" which he intimates is "the key to it all," Ishmael has attempted to sway the reader to his narrative purpose. The phantom-like image which the reader will pursue in the ensuing pages has been equated with the phantom-like image which the narrator will pursue in writing about his own past experi- 
ence. And Ishmael solidifies this cognitive pact between himself and the reader in the form of an "oath" during a "second-person" scrutiny of the painting in the Spouter-Inn:

But what puzzled most and confounded you was a long, limber portentous, black mass of something hovering in the centre of the picture over three blue, dim, perpendicular lines floating in a nameless yeast. A boggy, soggy, squitchy picture truly, enough to drive a nervous man distracted. Yet was there a sort of indefinite, half attained, unimaginable sublimity about it that fairly froze you to it, till you involuntarily took an oath with yourself to find out what that marvellous painting meant. Ever and anon a bright, but, alas, deceptive idea would dart you through-It's the Black Sea in a midnight gale.-It's the unnatural combat of the four primal elements. - It's the breaking-up of the ice-bound stream of Time. But at last all these fancies yielded to that one portentous something in the picture's midst. That once found out, and all the rest were plain. (p. 20)

"That" - the key which when "found out" resolves all other levels of inscrutability in the picture "and all the rest were plain"-turns out to be "even the great leviathan himself" (p. 20). The cognitive hunt is on, yet a full seventy chapters pass before "leviathan himself" can be physically apprehended and Ishmael may finally rejoin the reader to "lay together our" heads (p. 278) in order to examine this portentous "that" in detail. And during that interim, leviathan has literally assumed the status of an inaccessible phantom for both Ishmael and the reader. Although Ishmael endeavors "to take hold of whales bodily, in their entire liberal volume, and boldly sort them that way" (p. 123) in the "Cetology" chapter, he reminds the reader that in this approach to leviathan, "It is chiefly with his name that I now have to do" (p. 120). In the first attempt to capture the living creature, the "fictitious monster" (p. 193) not only eludes Ishmael's grasp, but his sight as well - the boat is swamped by the unseen flukes and a rising sea, leaving Queequeg to try and signal the ship with a lantern on a waif-pole: "There, then, he sat, holding up that imbecile candle in the heart of that almighty forlornness. There, then, he sat, the sign and symbol of a man without faith, hopelessly holding up hope in the midst of despair" (p. 195). The reader may well begin wondering whether the involuntary "oath" which Ishmael extracted from him in the Spouter-Inn has put him on the trail of a fact or fiction. Indeed, Ishmael returns to the medium of paint in the "Of the Monstrous Pictures of Whales" chapter, but of the various representations of the whale he shows the reader, "none can hit it with any very considerable degree of exactness"' (p. 228). Ishmael's concluding advice to the reader does not appear too heartening:

So there is no earthly way of finding out precisely what the whale really looks like. And the only mode in which you can derive even a tolerable idea of his living contour, is by going a whaling yourself; but by doing, you run no small risk of being eternally stove and sunk by him. Wherefore, it seems to me you had best not be too fastidious in your curiosity touching this Leviathan. (p. 228)

The atmosphere of utter uncertainty in which the white whale swims for 
Ahab and the crew of the Pequod applies equally to leviathan in general for the reader. His actual knowledge of the whale has been obscured throughout the first seventy chapters of the novel in much the same manner as the "morbid hints, and half-formed foetal suggestions of supernatural agencies" have "invested Moby-Dick with new terrors unborrowed from anything that visibly appears" (p. 156). Thus when the taking of a sperm whale follows hard on the heels of Stubb's right whale, the reader stands well-prepared to hear Ishmael's lesson in comparative anatomy lay bare the aura of mystery and make "all the rest ... plain." Ishmael commences this long-awaited commentary with relish-his language borders on that of a learned lecturer with his specimens at hand and his audience eagerly following his every word:

As the external difference between them is mainly observable in their heads; and as a head of each is this moment hanging from the Pequod's side; and as we may freely go from one to the other, by merely stepping across the deck:- where, I should like to know, will you obtain a better chance to study practical cetology than here? (p. 278)

In the first place, you are struck by the general contrast between these heads. Both are massive enough in all conscience; but there is a certain mathematical symmetry in the Sperm Whale's which the Right Whale's sadly lacks... (p. 278)

Let us now note what is least dissimilar in these heads- . . (p. 278)

Let us now with whatever levers and steam-engines we have at hand, cant over the sperm whale's head, so that it may lie bottom up; then, ascending by a ladder to the summit, have a peep down the mouth... (p. 280)

Crossing the deck, let us now have a good long look at the Right Whale's head. . . (p. 281)

Ishmael initially bespeaks all the assurances of an accomplished anatomist. He remains undaunted by the preliminary difficulties encountered in explicating what seems beyond comprehension, willing to consider certain unverifiable suppositions merely because they have "the savor of analogical probability" (p. 282). At one point he recapitulates his findings for the reader by stopping "to sum up" (p. 283). But in "The Battering-Ram" chapter, Ishmael's quasi-scientific discourse breaks down. Abandoning the relatively stable ground of comparative anatomy, he also leaves behind the factually rooted yet cursory observations on the physical structure of leviathan in order to probe the sperm whale's more perplexing peculiarities. Ishmael avers that "the Sperm Whale's head is a dead, blind wall. .." (p. 284) "inestimable by any man who has not handled it" (p. 285). And while he still makes reference to what "has hypothetically occurred to me" (p. 285), words such as "inexplicable," "mystical," and "unknown" find their places once again in Ishmael's language. He openly admonishes the reader by stating, "when I shall show you some of his more inconsiderable braining feats; I trust you will have renounced all ignorant incredulity, and be ready to abide by this; that though the Sperm Whale stove a passage through the Isthmus of Darien, 
and mixed the Atlantic with the Pacific, you would not elevate one hair of your eye-brow" (p. 285). The thrust seems clear-lessons in "practical cetology" have but a limited application. They provide little more than a tentative and superficial grid for gauging the mysteries of a creature who has "no nose, eyes, ears, or mouth; no face; he has none proper; nothing but that one broad firmament of a forehead, pleated with riddles" (p. 292). Certainly Ishmael is not insensitive to the straits in which this abrupt change in tone leaves his "monkey-rope" companion. In his indecisiveness over the nature of the whale's spout, Ishmael takes the reader's role for a moment to answer the obvious complaint that the orderly empiricism of "practical cetology" has collasped:

But why pester one with all this reasoning on the subject? Speak out! You have seen him spout; then declare what the spout is; can you not tell water from air? My dear sir, in this world it is not so easy to settle these plain things. I have ever found your plain things the knottiest of all. And as for this whale spout, you might almost stand in it, and yet be undecided as to what it is precisely. (pp. 312.13)

Finally Ishmael confesses, "Dissect him how I may, then, I go but skin deep; I know him not, and never will" (p. 318). Despite all the cognitive "cutting-in" and "trying-out," the whale escapes unscathed. In the last of the ostensible cetological meditations-the "Will He Perish?" chapter-leviathan swims away, still all of a piece, inscrutable, mysterious, and indomitable, spouting "his frothed defiance to the skies" (p. 385). If the reader recalls the painting in the Spouter-Inn, he cannot but realize "that" has not been "found out" and "all the rest" is not "plain." Yet Ishmael by no means wantonly severs the "monkey-rope" nor forces a gullible reader to thread his own way through the uncertainties of the novel's final pages. For while Ishmael leads the reader on in a search for a meaning, he also makes the reader aware why one meaning is not forthcoming and why "your plain things" may be "the knottiest of all." In a sense, Ishmael's overt instructions to the reader merely serve as a disguise for a series of covert instructions which are designed to make the reader aware that he is engaged in the act of cognition, i.e., the act of reading and "raising a meaning" from Moby-Dick. Rather than prescribing a theory of epistemology, Ishmael consistently points out the limits of one's habitual and familiar knowledge as a basis for cognition. His narrative method in this respect has already been suggested in the "Wheelbarrow" chapter. Ishmael anticipates the reader's reaction to Queequeg's shouldering of the wheelbarrow by commenting "you might have known better than that, one would think" (p. 59), and thereby puts the reader in the position of receiving Queequeg's rejoinder. The effect is clear-the reader, like the "civilized" sea captain who visits Kokovoko, interprets what is unfamiliar by making it familiar.

Throughout the chapters in which he relates his initial meeting with Queequeg, Ishmael uses himself to illustrate the discrepancy between one's familiar sphere of knowledge and the unfamiliar. While awaiting his har- 
pooner's arrival in the bedroom at the Spouter-Inn, he seizes upon a peculiar item: "I took it up, and held it close to the light, and felt it, and smelt it, and tried every way possible to arrive at some satisfactory conclusion concerning it. I can compare it to nothing but a large doormat" (p. 27). The object does not yield its mystery to Ishmael's visual, tactile, and olfactory probings - it cannot be comprehended without recourse to an analogy with the familiar "doormat," which, as Ishmael fails not to remind the reader, provides no adequate explanation either: "But could it be possible that any sober harpooner would get into a doormat, and parade the streets of any Christian town in that sort of guise?" (p. 27). Queequeg himself presents no less a mystery upon entering the room. The absurdly jocular tone in Ishmael's description of Queequeg as a man with "a mildewed skull ... a stickingplaster shirt" and "legs. . .marked, as if a parcel of dark green frogs were running up the trunks of young palms" (p. 29), simply points out the distortion inherent in perceiving the unfamiliar in terms of such familiarities. When Queequeg clambers under the bed in order to put his boots on, Ishmael remarks that "by no law of propriety that I ever heard of, is any man required to be private when putting on his boots" (p. 34). Queequeg performs "some sort of Lent or Ramadan, or day of fasting, humiliation and prayer," and Ishmael observes that "how" it was I could never find out, for, though I applied myself to it several times, I could never master his liturgies and XXXIX Articles" (p. 66). In such passages Ishmael covertly urges the reader to become aware of the inefficacy that his own "laws of propriety" and "XXXIX Articles"- - his habitually ingrained reality-will have in the pages ahead. For the problem of interpreting the unfamiliar does not find expression only in the contrast between "civilized" and "savage" man. Nor does Ishmael hesitate to inform the reader why an awareness of his habitual reality will prove necessary for the act of reading the novel:

So ignorant are most landsmen of some of the plainest and most palpable wonders of the world, that without some hints touching the plain facts, historical and otherwise, of the fishery, they might scout at Moby Dick as a monstrous fable, or still worse and more detestable, a hideous and intolerable allegory. (p. 177)

Here Moby Dick might well be Moby-Dick, for Ishmael places paramount importance on the reader's reception and interpretation of the words of the text. The "landsman" who brings his own familiar and habitual contextual code to the unfamiliar world of the text would necessarily project that context onto the novel as the context which governs the significance of objects and phenomena - just as the various characters do in their "reading" of the doubloon-unless the text itself anticipates this action on the reader's part and calls his familiar context into question. Indeed, Ishmael's most vital function as narrator may well consist of his efforts to prevent the cognitive drive which he arouses in his reader from turning both Moby Dick and Moby-Dick into "a hideous and intolerable allegory." The reader, then, finds 
that the whaling ship itself-which Ishmael appropriately calls "my Yale College and my Harvard" (p. 101) - provides not only an introductory course in "the mysteries of whaling" (p. 58), but also a means of awakening the reader to his "landed" perspective. The perception of the world by a "whaleman" and a "landsman" may differ as much as between "savage" and "civilized" man. The familiar and the unfamiliar as defined by the habitual experiences of each group may even be mutually exclusive, because "for years he (the whaleman) knows not the land; so that when he comes to it at last, it smells like another world, more strangely than the moon would to an Earthsman" (p. 63). In this light, Ishmael's leading of the reader from the mysteries of Queequeg to "the mysteries of whaling" is not at all incongruous: "Long exile from Christendom and civilization inevitably restores man to that condition in which God placed him, i.e. what is called savagery. Your whale-hunter is as much a savage as an Iroquois" (p. 232).

Certainly much of the specialized vocabulary and actual workings of the whaling ship explained by Ishmael form a part of the reader's whaling education. In several chapters, such as "The Line," Ishmael indeed tells the reader that such explanations serve "for the better understanding of all similar scenes elsewhere presented" (p. 238). The reading of Moby-Dick, however, will not make one a whaleman any more than it will give him the "double" eyesight of the sperm whale, and Ishmael's use of the whaleman as someone who has been "forced into familiarity" (p. 158) with the unfamiliar functions primarily as a tool to dislodge the reader's habitual context of "landedness" as a cognitive foundation. Such sights as "in mountainous countries. . .the profiles of whales defined along the undulating ridges" are visible only to "a thorough whaleman" (p. 233), and in other passages Ishmael further reinforces the assertion that the landsman remains blind to certain phenomena:

As the three boats lay there on that gently rolling sea, gazing down into its eternal blue noon; and as not a single groan or cry of any sort, nay, not so much as a ripple or a bubble came up from its depths; what landsman would have thought, that beneath all that silence and placidity, the utmost monster of the seas was writhing and wrenching in agony! (p. 300)

Nevertheless, the experimental world of the whaleman does not posit for the reader a context through which the significance of things may be perceived. In a qualification of his comparison of the whaleman to a savage, Ishmael claims, "I myself am a savage, owning no allegiance but to the King of the Cannibals; and ready at any moment to rebel against him" (p. 232). The metaphor indicates that Ishmael not only rejects adopting any single contextual perspective, but also proposes no single context to the reader, for to do so would necessarily place interpretive borders on the symbolic potential of objects and phenomena. The use of the "whaling" world as opposed to the "landed" world is, more properly, a device by which Ishmael creates for the reader a state of utter "landlessness," a state in which the 
"harborless immensities" of the sea itself can suggest an essentially fluid contextual horizon that reveals the symbolic plurality of things through a perpetually shifting "illumining" background:

So, though in the clear air of day, suspended against a blue-veined neck, the pure-watered diamond drop will healthful glow; yet, when the cunning jeweller would show you the diamond in its most impressive lustre, he lays it against a gloomy ground, and then lights it up, not by the sun, but by some unnatural gases. Then come out those fiery effulgences, infernally superb; then the evil-blazing diamond, once the divinest symbol of the crystal skies, looks like some crown jewel stolen from the King of Hell. (p. 345)

Thus Ishmael displays particular care in pointing out that his own experiences of an insight into the nature of things are inextricably tied to a specific though fleeting and transient set of perceptual conditions, and that such insights do not represent purely transcendental moments which exist on the level of a "thing in itself." His remarks on the workings of "chance, free will, and necessity" in "The Mat-Maker" chapter, for example, cannot be divorced from his prefatory remarks on how that perception came about: "I say so strange a dreaminess did there then reign all over the ship and all over the sea, only broken by the intermitting dull sound of the sword, that it seemed as if this were the Loom of Time" (italics mine, p. 185). Likewise, Ishmael's vision of "long rows of angels in paradise, each with his hands in a jar of spermaceti," in the "A Squeeze of the Hand" chapter, remains firmly rooted in the temporary concatenation of several factors:

As I sat there at my ease, cross-legged on the deck; after the bitter exertion at the windlass; under a blue tranquil sky; the ship under indolent sail, and gliding so serenely along; as I bathed my hands among those soft, gentle globules of infiltrated tissues, woven almost within the hour; as they richly broke to my fingers, and discharged all their opulence, like fully ripe grapes their wine; as I snuffed up that uncontaminated aroma,literally and truly, like the smell of spring violets; I declare to you, that for the time I lived as in a musky meadow; I forgot all about our horrible oath; in that inexpressible sperm, I washed my hands and heart of it. . (italics mine, p. 348)

For the reader, too, landlessness consists of precisely such momentary and transient glimpes into the symbolic world of Moby-Dick. Yet no single perception or insight can be extracted from the flux of landlessness as a "true" or "real" cognition any more than one may identify one "true" appearance of "the pure-watered diamond drop." And although Ishmael himself recoils from the "illumining" light of the fire in "The Try-Works" chapter and proclaims "the natural sun ... the only true lamp-all others but liars!" (p. 354), he cannot avoid adding, "Nevertheless the sun hides not Virginia's Dismal Swamp, nor Rome's accursed Campagna, nor wide Sahara, nor all the millions of miles of deserts and of griefs beneath the moon. The sun hides not the ocean, which is the dark side of this earth, and which is two thirds of this earth" (pp. 354-55). The sun may remove Ishmael's "unnatural hallucination of the night" (p. 354), but will in turn illuminate other visions no more "kind to our mortalities." Man seems incapable of resolving the 
dialectic between his desire for contextual stability in the world itself and the landlessness which keeps his cognitive efforts in a cycle of flux and process:

Would to God these blesssed calms would last. But the mingled, mingling threads of life are woven by warp and woof; calms crossed by storms, a storm for every calm. There is no steady unretracing progress in this life; we do not advance through fixed gradations, and at the last one pause:- through infancy's unconscious spell, boyhood's thoughtless faith, adolescence' doubt (the common doom), then scepticism, then disbelief, resting at last in manhood's pondering repose of If. But once gone through, we trace the round again; and are infants, boys, and men, and Ifs eternally. (p. 406)

In these "mingled, mingling threads of life" Ishmael weaves a narrative which simultaneously feeds and denies the reader's cognitive impulse. Not only is the world landless in its ceaseless change and transformation, but man is also landless in that he does not constitute a stable being in his temporal existence. With both perceiver and perceived in constant "motion," the ontological verification of an all-subsuming context through which an absolute act of cognition may be effected can become both a "monomania" and a "monophobia." For the reader that quest is endless-he must "trace the round again"- -because, like Ishmael's narrative, the quest is circular. In the temporality of the reading process he does "not advance through fixed gradations, and at the last one pause," but rather reaches the "Epilogue" in which the quotation from the Book of Job leads him back to the telling of the tale, that is, the "beginning" of Moby-Dick. The implied circularity of the narrative serves as a metaphor for the reader's textual experience of cognitive landlessness, as the form itself precludes one's ability to select a specific part of the circle which embodies the experience of circularity more than another part. Ishmael creates a verbal structure designed to give the reader the experience in language of "that mortally intolerable truth" that "in landlessness alone resides the highest truth, shoreless, indefinite as God" (p. 97). Yet only by engaging the reader's cognitive impulse can Ishmael lead him to glimpse "the highest truth" which is beyond cognition, just as only by engaging the reader's habitual experiental context can Ishmael reveal that the context for Moby-Dick is no context. The novel cannot, therefore, be interpreted in the sense of naming or identifying meaning - it exists only to be experienced by the reader in the act of reading. And that experience is guided by the dynamic interaction between Ishmael and the reader as well as by the dialectical interplay of the cognitive drive and its impossibility of fulfillment-contrary pressures which exert a force on the reader's movement through the text like the contradictory winds that move the Perquod in "The Spirit-Spout" chapter: ". . . she rushed along, as if two antagonistic influences were struggling in her-one to mount direct to heaven, the other to drive yawingly to some horizontal goal" (p. 200). In this dialectic the novel achieves its peculiar parity and commensurability with "the ungraspable phantom" which it ostensibly fails to capture-Moby-Dick itself becomes the phantom for the reader. 
1 Herman Melville, Moby-Dick, eds. Harrison Hayford and Hershel Parker (New York: W. W. Norton \& Company, 1967), p. 59. All subsequent quotations from Moby-Dick will be followed by page numbers which refer to this edition.

2 Ernest Cassirer, The Philosophy of Symbolic Forms, 3 vols. (New Haven: Yale University Press, 1953), vol. 1: "Language," trans. Ralph Manheim, p. 98.

3 Carey H. Kirk, "Moby-Dick: The Challenge of Response," Papers on Language and Literature, 13, No. 3 (Fall 1977), p. 390.

4 Robert Zoellner, The Salt-Sea Mastodon: A Reading of Moby-Dick (Berkeley: University of California Press, 1973), p. 11.

5 Walter E. Bezanson, "Moby-Dick: Work of Art," in Moby-Dick Centennial Essays, eds. Tyrus Hillway and Luther S. Mansfield (Dallas: Southern Methodists University Press. 1953), p. 48.

6 A. Robert Lee, "Moby-Dick: The Tale and the Telling," in New Perspectives on Melville, ed. Faith Pullin (Kent, Ohio: The Kent State University Press, 1978), p. 112.

7 Warwick Wadlington, The Confidence Game in American Literature (Princeton: Princeton University Press, 1975), p. 94. Wadlington examines many of the same passages as I do from the "Loomings" chapter, but sees them as "an epitome of the way Ishmael's rhetoric engenders selftaste by manipulating the reader's distance from him and the world of his fiction" (p. 92). 